\title{
Emergence, Institutionalization and Professionalization of Romanian Journalism in the 19th Century
}

\author{
Iulian Bitoleanu \\ National High School Anastasescu, Republicii Street no. 11, Rosiori de Vede, \\ Teleorman, Romania \\ E-mail address: bitoleano_iulian@yahoo.ro
}

\begin{abstract}
The study investigates the roots of journalism in Romania. First is ascertained the inextricable connection of the Romanian journalism with the European journalism. Then is revealed the delayed imposing of the press in the Romanian principalities in the early part of the 19th century. Moreover, it highlights the rapid evolution of the Romanian press and its axiological synchronization with European and world press towards 1880, through national poet Mihai Eminescu and the newspaper "Timpul" ("The Time").
\end{abstract}

Keywords: journalism; history of journalism; press; history of press

\section{INTRODUCTION}

Culture is inconceivable without its bookish size, without contribution of "hewed accent", embodied in artistic literature (poetry, prose, theatre) or scientific (treaties, dictionaries). The press belongs also of the culture zodiac, of the written communication. Victor Vişinescu (Vişinescu, 2004, p. 12), asserts that, were four revolutions that marked communication; the first: articulated language (the proto-history); the second: alphabet and writing (with thousands of years B.C.); the third: the printing press, invented by Gutenberg (the 15th century, in 1438) and last: technologization in mass media, by Marshall McLuhan (Borowski, 2013a; Strechie, 2009; Strechie, 2010). A relevant point of view expressed also Melvin L. De Fleur and Sandra Ball-Rokeach (Du Fleur \& Ball-Rokeach, pp. 21-38) who have revealed six phases of communication in diachrony: The Signs and Signals Age; The Speech Age; The writing Age; The Printing Press Age, The Media Mass Age; The Information Age.

On 1438 remains a landmark in the history of mankind in broadcasting to thousands of miles of the messages, in faster flow of information, commissioning, rightly, the Gutenberg galaxy, if we consider that Johannes Gensfleisch, alias Johan Gutenberg of Mainz (14001468) created in Strasbourg, and Mainz, the printing press, fascinating medieval invention, an opportunity to print the Bible (1455 - 1456) and other fundamental works (Vlăduțescu, 2014; Păun, 2014). About the special significance of the event was pronounced also Marshall McLuhan (McLuhan, 1975, p. 450). With Gutenberg, Europe goes into technological phase 
of the progress, phase in which the change itself becomes the archetypal norm of the social life. The typography tended "to make the language from a mean of perception and exploration in a transportable commodity", insisting on the dual valences of technology and raw material, superior to cotton and wood. The father of printing press did not have an existence of light, as his epochal discovery. The legend says that he would have gone bankrupt, his spiritual "wealth" - about 200 copies of the "Bible" - and the shop beeing claimed by personal attorney (Popa, 2002, p. 108). Untill the press appearence there was only one step: the manufacturers of news and rumors contrived - shows Pierre Albert (Albert, 2002, pp. 12-13) - some file called occasional booklets, with the aspect of small books (end of the 15th century), recounting battles, funerals, social events, cultural, encouraging debate, especially political and religious.

Written communication can live also without media? Absolutely, not! At its origin stayed - thinks Florea Ioncioaia (Ioncioaia, 2000. p. 29) - "freedom of expression and cultural challenge."

From the history of the press, before gazettes, we remind: posters, pamphlets, almanacs (the first dating from 1486), timeline (a kind of reviews on the major events, 1588, Germany), religious brochures and publications with popular character named "canards" (Popa, 2002, p. 117), in France. Latest extremely spectacular, acceptance of the reading public, greedy of sensational. "Characteristic for "canards" is that they brought to inform the general public all the real news or imaginary that could strike imagination and sensitivity: floods, earthquakes (...) and especially, spectacular crimes ..."). Samples of early printed media were registered in Germany, France, England, Italy. All these appearance forms of scriptural communication, have led up for the first newspapers: bi-monthly "News of Antwerp" (1605 - 1607) and a hebdomadal of the same year, 1605, in Strasbourg. So the cradle of print media was in the Netherlands and the Franco-German haven.

Step by step, propagation of press media inundates Western Europe: Stuttgart, Prague (1619), Cologne, Amsterdam (1620), London (1620), Florence (1636), Rome (1640), Madrid (1661). A weekly escaped of "night of forgetfulness" was the Parisian "La Gazette" of only 4 pages (May 1631) of Renaudot Theophraste physician, with a circulation of 1200 copies.

Even if the first journalists came from the writers and philosophers categories, there were also criticist fellows at the press dilettantism. Thus, the Enlightenment J. J. Rousseau and Voltaire (Apud Albert, 2002, p.19) were reserved concerning draing out the journalism from the pseudoliterature slough: "What is a periodical? A paper without merit and without utility, whose neglected and despised reading of the book knowing not only to provide women and fools vanity without training". In addition, the press seemed "a story of nothings". The press enthusiasm of the Enlightenment, explained by the of recoil absolute monarchy and effectively enrolling of writers in the press, has facilitated the euphoric launch of the first newspaper, in 1660: "Leipziger Zeitung" (extended untill 1921), the alert and diverse by news.

Scanning the situation from Europe by powerful sources (Balle, 1990), it should be noted that major newspapers are born to the late 18th century: "Journal de Paris" (1777), "Gazette de France", "Quotidienne", "Journal des Debats", "La Presse" (with a circulation of 180,000 copies), "Times"(1785), "Daily Telegraph" (1855), "Algemeine Zeitung" (1798 Tubingen), many survived through centuries, offering models of objectivity and professionalism.

Regarding the literature-press relationship, it had a monochrome appearance in England (prose writers adhesion to journalism) and other divergent in France (of acceptance as a hobby, to assume fervent times of skepticism from Diderot and Montesquieu Encyclopedias). 
Occupational hazard can result in dramatic arrests (Daniel Defoe) or tragic (the death penalty). For example, in 1794, a notorious writer Simeon Liriguet was beheaded (Popa, 2002, p. 108).

\section{APPEARANCE OF THE PRESS IN ROMANIA}

On 1829 marks the birth of the Romanian press through "Curierul Românesc" (his I.H. Radulescu's hebdomandal, in Muntenia) and "Albina Românească" (the Gh. Asachi's bimonthly in Moldova). Transylvania could not be outdone, the name of George Bariţiu (Gazeta de Transilvania, on March 12, 1838, Braşov), coming, of course, in the category of newspaper pioneering.

Human spirituality is weighed not only in artistic works, scientific, cultural acts, inventions etc., but also in the mass media. Mirror of reality at all levels - social, political, economic, cultural, recreational, journalism has registered here and there here and there a fulminate rise, here emancipating collective consciousness, boosting the course of history, apostrophizing, haloing facts, individuals, in accordance with the truth (Nowicka-Skowron, Dima \& Vlăduţescu, 2012).

Never asynchronous what is happening in Europe, Romanian intellectuals of bourgeois century, schooled in France, then in Germany, implant the national book tribute, which opens a new communicational section the press. As shows Luminiţa Rosca (2000) in the decade 1840-1850 occurs journalism professionalizing, when tens of periodic flood the market, especially radiating from Iasi ("Osiris", "Foaia Sătească", "Dacia literară", 1840, "Arhiva", "Spicuitorul", "Dunărea", "Alăuta Românească”) şi Bucureşti ("Muzeul Naţional", "Gazeta Teatrului Naţional", "Cuviosul Românesc", "Pământeanul”, "Mozaicul"). In two decades then occurr press institutionalization, through an explosion of newspapers (forty-eighter press to which is inserted also "Poporul Suveran" (responsible Dimitrie Bolintineanu), "Pruncul român" (C.A. Rosetti - founder), "Reforma" (conceived by A.I. Cretescu), "Bucovina" (designed by Hurmusachi brothers) (Dima, Grabara \& Vlăduţescu, 2012; Dima \& Vlăduţescu, 2012a) .

As for Transylvania nothing of effervescence, but dissipation of journalistic latencies from Brasov ("Gazeta de Transilvania", 1838) to Sibiu ("Amicul Şcoalei", 1860), Arad ("Mugurii") and Oradea ("Zorile Bihorului", 1854). Press founders were I. H. Rădulescu, Gh. Asachi (decade 3), G. Bariţiu (decade 4), M. Kogălniceanu, V. Alecsandri ("România Liberă", 1855), D. Bolintineanu ("Dâmboviţa", 1858), N. Bălcescu (with A. T. Laurian "Magazin istoric pentru Dacia"), Cezar Bolliac ("Buciumul", Paris, 1857). We do not insist on cultural publications - they are not the subject of our research - nowise on establishing a top of periodicals. Otherwise, we could advance only reminding N. Iorga (N. Iorga - The history of Romanian press, Romanian Literature Museum Publishing, Bucharest, 1998), which established 7 stages in the evolution of Romanian press, with 5 being before Eminescu: "1. "Dibuiri şi Începuturi"; 2. "The first legal publications. Age of Eliad and Asachi"; 3. "Cultural press, politics of generation 1840"; 4. "Romanian revolutionary and reformist press during 1848-1859"; 5. "Romanian Press after the Union of the Principalities".

Chronological and political criteria we added also the theme, that the press configuration of the bourgeois century would look like:

a) Conservative press ("Timpul", 15.03.1866-1884, “Ţara”,1869-1870, "Constituţiunea", 1867-1870, "Convorbiri literare", 1867);

b) The Liberal press (initiator - C.A.Rosetti) illustrated by: “Românul”, 1856-1951; 
“Trompeta Carpaţilor" (of Cezar Bolliac); "Traian”;

c) The Socialist press (after 1872);

d) The cultural-artistic press ("România pentru ştiinţă, literatură, arte", 1861-1863);

e) The Humoristic press:

f) The theological press (a little represented).

Regarding the name of periodicals, there is a certain stereotype, predominantly headlines like: "Foaia", "Gazeta", "Curierul". An interesting article of Eminescu, on press issues, was entitled "Notiţe Bibliografice", which is punished the "gibberish", "cosmopolitan", the impassivity beside orality of the style, lack of the profound ideas ...

Newspapers has thriven (What good so many publications? What was their goal?) when real journalists were not true, maybe a Rosetti (engaged press of 8-9 decades in "Timpul" and "Românul" particularly, has built its reputation thanks of two "mythical figures," as Ioncioaia Florea expression, (Introduction to the written press, University "AI Cuza" Publishing, 2000, p. 43), M. Eminescu and C.A. Rosetti), a Bolliac (Vlăduţescu, 2004; Vlăduţescu, 2006; Vlăduţescu \& Ciupercă, 2013).

The publicists came from literary category, writers, a sign that the profession is not institutionalized. Moreover, for Al. Andriescu (Al. Andriescu, Style and language, Junimea 1977, chapter "The language of Romanian press towards the literary language styles", pp. 239-251) stylistic differences between journalists were minor, insignificant. Therefore we shall reiterate the idea that the first authentic journalist and, also the most valuable of democratic age was Eminescu, especially after the appearance of journalistic sextet: "Old icons and new icons" in "Timpul" (Smarandache \& Vlăduţescu, 2014) .

\section{3. "TIMPUL" ("THE TIME") - THE MOST IMPORTANT ROMANIAN MEDIA OPERATOR OF 19th CENTURY}

With the name "Timpul" there were two journals. First, weekly newspaper, published in Bucharest, between $16^{\text {th }}$ of December 1854 and $20^{\text {th }}$ of January1855, and between $17^{\text {th }}$ of December 1856 and $4^{\text {th }}$ of April 1857, reappeared on $22^{\text {nd }}$ of December 1860 until $5^{\text {th }}$ of February 1861, with the first editor Gr. R. Bossueceanu, and among the signatories C.D. Aricescu, Gh. Sion, B.P. Mumuleanu. The second was a political and literary journal, with four weekly times between $15^{\text {th }}$ of March and $16^{\text {th }}$ of May 1876 , then daily from $17^{\text {th }}$ of May 1876 and $17^{\text {th }}$ of April 1884, and $13^{\text {th }}$ of November to $14^{\text {th }}$ of December 1900.

Official newspaper of the Conservative Party it had director of prestige, Titu Maiorescu, Gr. G. Păucescu, and caliber editors, among them M. Eminescu (December 1880February 1881), which says a lot about the artistic bar. In the six years at "Timpul" (18771883) Eminescu was not remained a simple editor, a minister of the pen, executor of party politics, nobody could seize his strong personality in the ideological patterns, hence the outbursts against donor or logos independence, sometimes, troublesome for rulers. Rebel journalist, objective, Eminescu has opened many belligerent arenas, excluding transient solution of withdrawal. When the truth demanded, he criticized his superiors, for instance the influential conservative leader Al. Lahovari and even Junimists friends, Titu Maiorescu and P.P. Carp. His ardent patriotism not tolerate obedient attitude of politicians "white / red" beside the great powers. Not knowing what is fear, demanding and courageous publicist often criticized adjacent empires forces, Russia and Turkey (Strechie, 2008; Vlăduţescu, 2013a; Vlăduțescu, 2013b). Three of the Romanian literature classics, Eminescu, Caragiale and Slavici, have aligned "Timpul" on the trajectory of the value newspapers, resisting to all 
kinds of pressures and preserving the editorial triangle solidarity. The poet's decay (May 1883), correlated with the merger of the "Timpul" with other publications, ideological inconsistencies of conservatives leaders and installing of M. Paleologu as director triggered the decline. About the exception journalist was reported that "he ceased to take part in the editor." Hanging about on the glorious periods, should be evident that the polyvalent editor, after exhausting experiment of "Curierul de Iaşi" ("page of the stray cattle") is exhilarating and reflective launch, by trampoline "Timpul", for the less-known, achieving genuine studies of sociology, political analysis, economics, pedagogy and culture theory. In addition to the relevant journalist vocation, unmistakable and inconvenient, Eminescu reveals also its facet of distinguished intellectual, erudite. The aura of celebrity in subjects other than history, philosophy and Germanistic block ease off of journalistic canon which, at that time, accepts the caste anyone have something to say and possibly had an agreeable exposure manner of ideas. Rather, Eminescu illustrates, the atypical journalist, highly trained, cultivated, acerbic polemicist, devouring foreign press and owner of a very rare argumentative techniques.

\section{CONCLUSION}

Although Burke decreed in 1787 the press as being the fourth power in state, however, the fate of the press in England (between 1621 and 1791) was an agitated one, because of political instability, civil war. For Pierre Albert (Albert, 2002, p. 21), the eighteenth century was dominated by the Daniel Defoe's grace pamphleteer (founder of "Revue" between 1704 and 1713). French Press (1653 - 1678) has developed slowly, while German therefore, after a period of censorship, suddenly blossomed. Note that the "Declaration of the Rights of Man and Citizen" of $26^{\text {th }}$ of August1789, Article 10, proclaimed the right to opinion of every citizen, and Article 11 states the principle of freedom to publish (Vlăduţescu, 2002; Cotoc, Traistaru \& Stoica, 2013).

In Romania, the press appeared around 1830. It was institutionalized toward 1850 and it was professionalized to 1860. Through media operator "Timpul" and the great poet and journalist Mihai Eminescu to 1880, Romanian journalism climbed to an outstanding altitude, European and worldwide.

\section{References}

[1] Borowski A. (a), International Letters of Social and Humanistic Sciences 1 (2013) 14-18.

[2] Vişinescu, V. (2004). O istorie a presei româneşti. Bucureşti: Victor, Bucureşti.

[3] Dziwańska K., International Letters of Social and Humanistic Sciences 7 (2013) 96-112.

[4] Du Fleur M. L., Ball-Rokeach S. (1999). Teorii ale comunicării de masă. Iaşi: Polirom.

[5] McLuhan M. (1975). Galaxia Gutenberg. Bucureşti: Politică.

[6] Borowski A. (b), International Letters of Social and Humanistic Sciences 6 (2013) 68-74.

[7] Mădălina Strechie, International Letters of Social and Humanistic Sciences 7 (2014) 56-61.

[8] Popa D. (2002). Mass-media, astăzi. Iaşi: Institutul European. 
[9] Albert P. (2002). Istoria presei. Iaşi: Institutul European.

[10] Borowski A. (c), International Letters of Social and Humanistic Sciences 7 (2013) 113-118.

[11] Ştefan Vlăduțescu (d), International Letters of Social and Humanistic Sciences 6 (2014) 49-54.

[12] Ioncioaia F. (2000). Introducere în presa scrisă. Iaşi: Ed. Univ. A. I. Cuza.

[13] Jeanenney J.-N. (1997). O istorie a mijloacelor de comunicare. Iaşi: Institutul European.

[14] Ştefan Vlăduţescu (e), International Letters of Social and Humanistic Sciences 7 (2014) 8-13.

[15] Balle F. (1990). Medias et societes. Paris: Montchrestien.

[16] Raduică G., Raduică N. (1955). Dicţionarul presei româneşti. Bucureşti: Ştiinţifică.

[17] Cotoc E. A., Traistaru A., Stoica A., European Journal of Humanities and Social Sciences 25(1) (2013) 1316-1325.

[18] Dima Ioan Constantin, Vlăduţescu Ştefan (2012a). Persuasion elements used in logistical negotiation: Persuasive logistical negotiation. Saarbrucken: LAP Lambert Academic Publishing.

[19] Dima Ioan Constantin, Vlăduţescu Ştefan (b), European Journal of Business and Social Sciences 1(6) (2012) 27-33.

[20] Nowicka-Scowron, Maria, Dima, Ioan Constantin, Vlăduţescu, Ştefan, International Journal of Management Sciences and Business Research 1(8) (2012) 27-35.

[21] Mihaela-Gabriela Păun, International Letters of Social and Humanistic Sciences 6 (2014) 42-48.

[22] Vlăduţescu Ştefan (a). International Journal of Management Sciences and Business Research 2(8) (2013) 1-9.

[23] Siminică M., Traistaru A. Self-Directed Learning in Economic Education. International Journal of Education and Research 1(12) (2013).

[24] Vlăduţescu Ştefan (c), International Journal of Education and Research (2013) 1(11).

[25] Smarandache F., Vlăduţescu Ş. Communication vs. Information, an Axiomatic Neutrosophic Solution. Neutrosophic Sets and Systems, 38.

[26] Vlăduţescu Ştefan (2002). Informaţia de la teorie către ştiinţă. Propedeutică la o ştiinţă a informației. Bucureşti: Editura Didactică şi Pedagogică.

[27] Vlăduţescu Ştefan (2004). Argumentaţia şi demonstraţia ca moduri de impunere. Craiova: Editura Sitech.

[28] Dima Ioan Constantin, Grabara Janusz, Vlăduțescu Ştefan, Journal on Business Review 2(2) (2012) 4.

[29] Smarandache F., Vlăduţescu Ş. (2014). Neutrosophic Emergences and Incidences in Communication and Information. Saarbrucken: LAP Lambert Academic Publishing.

[30] Vlăduţescu Ştefan (a), Jokull Journal 63(8) (2013) 186-197. 
[31] Vlăduţescu Ştefan (b), Jokull Journal 63(9) (2013) 301-318.

[32] Strechie M. (2008). Condiţia femeii în cadrul familiei romane de origine ecvestră în perioada Principatului. Universitaria.

[33] Strechie M., Terms of Latin Origin in the field of Communication Sciences. Studii şi cercetări de Onomastică şi Lexicologie (SCOL) II (1-2) (2009) 203.

[34] Traistaru Aurelia (a), Jokull Journal 63(9) (2013) 125-135.

[35] Strechie Mădălina (2010). O istorie a mentalităţilor şi a mijloacelor de comunicare din preistorie şi antichitate. Craiova: Editura Universitaria.

[36] Traistaru Aurelia (b), Business Management Dynamics 3(2) (2013) 111-114.

[37] Vlăduţescu Ştefan (2006). Comunicare jurnalistică negativă. Craiova: Editura Sitech.

[38] Vlăduţescu Ştefan (2013b). The Communication Membranes. European Scientific Journal, 9.

[39] Vlăduţescu Ştefan (c). International Journal of Education and Research 1(12) (2013).

[40] Vlăduţescu Ştefan. American International Journal of Contemporary Research 3(10) (2013).

[41] Vlăduţescu Ştefan. Eight computational-communicative operations of building information. Mitteilungen Klosterneuburg Journal.

[42] Vlăduţescu Ştefan, Ciupercă Ella Magdalena (2013). Next Flood Level of Communication: Social Networks. Aachen: Shaker Verlag. 